\title{
C-peptide increase in chronic type 1 diabetic patients treated with autologous bone marrow cell transplantation through pancreatic artery catheterization: Three years follow-up
}

\author{
Alejandro Mesples ${ }^{1^{*}}$, Shu Jiang ${ }^{2}$, Yun Zhang ${ }^{2}$, Zhaoxia Luo ${ }^{2}$, Xiang Hu$^{2^{\star}}$ \\ ${ }^{1}$ Diabetes Education and Research, Buenos Aires, Argentina; ${ }^{*}$ Corresponding Author: amesples@yahoo.com.ar \\ ${ }^{2}$ Shenzhen Beike Cell Engineering Research Institute, Shenzhen, China; ${ }^{*}$ Corresponding Author: publication@beikebiotech.com
}

Received 1 October 2012; revised 3 November 2012; accepted 5 December 2012

\begin{abstract}
Background: Recent extensive clinical evidence demonstrated that autologous adult stem cell therapy was safe and effective as a treatment strategy for type 1 diabetes. Our initial work was designed to examine the safety and efficacy of the implantation technique on 20 subjects with six months of evolution. This new report analyzes the results from three years follow up. Methods: With the authorization from the Ministry of Health of Argentina, 20 subjects with type 1 diabetes were treated with single autologous bone marrow cell transplantation into pancreatic blood flow through pancreatic artery catheterization immediately after bone marrow aspiration. The primary endpoint was defined as normalization of C-peptide and glycated hemoglobin (HbA1c) with insulin independence at 3 years posttreatment. Results: 15 subjects $(75 \%)$ achieved clinical improvements. 7 subjects $(33 \%)$ reached the primary endpoint, in which 4 subjets with decreased C-peptide levels required insulin administration again at 3 years post-treatment. Other 8 subjects (34\%) showed partial function at 3 years post-treatment. There were no serious adverse events observed. No increases of islet cell antibody (ICA) and glutamic acid decarboxylase (GAD) antibody. Conclusion: This procedure may be a safe and effective treatment for chronic type 1 diabetes. The follow-up results showed a significant increase of the pancreatic secretion of C-peptide and a decrease in the daily dose of exogenous insulin. This effect partially disappears by the three years follow-up without an increase of the level of the ICA and GAD antibodies.
\end{abstract}

Keywords: Diabetes; Bone Marrow; Adult Stem Cells; Catheterization

\section{INTRODUCTION}

In type 1 diabetes, significant destruction of b-cells occurs prior to diagnosis. At the time of clinical onset, only $10 \%$ of normal b-cell mass remains [1]. Levels of plasma C-peptide drop to $20 \%$ of the maximal mean of healthy people [2]. A prospective study found that 2 years after diagnosis, insulin levels, after a mixed-meal stimulation, decreased to nearly $30 \%$ of baseline [3]. Similar findings contribute to therapeutic treatment that b-cells are nearly destroyed several years after diagnosis, especially with early age of onset. Studies show that patients with advanced disease do show some residual b-cell function, depending on individual variables [4-7]. Low or vanished C-peptide levels are indicative of advancing disease after diagnosis, and undetectable C-peptide is usually observed after 1 year of disease duration. Several studies recognized that C-peptide measurement is the best way to observe endogenous pancreatic function.

Recent studies have been trying to replace the functional mass of pancreatic islets destroyed by the autoimmune attack in type 1 diabetes [8-11]. Pancreas and pancreatic islets transplantations are two alternatives under consideration $[12,13]$. However, the considerable problems issued by both techniques are the low availability of donors, the technical complexity, immunosuppression after transplantation and the uncertain treatment results.

Several studies have described the regenerative capacity of stem cells, which can repair cellular injury in all tissues. Although the extent of their plasticity is still under investigation, studies within the last few years have demonstrated the capacity of these adult stem cells to differentiate into cells of lineages such as hepatocytes, renal cells, pancreatic islets and even early astrocytes [14-20]. 
The mechanisms of stem cell migration, adhesion and differentiation mediated by local chemokines were reported in recent publications $[21,22]$.

Because these cells do not have the ethical or tumorigenicity problems of embryonic stem cells, their plasticity have generated much excitement, giving hope to their therapeutic use in a wide range of diseases.

The observed beneficial effects of adult stem cell transplantation have led to numerous human clinical trials in the past several years. The use of adult stem cells in myocardial infarction showed a significant improvement in ventricular function [23-27]. Stem cell transplants in blood malignancies such as leukemias demonstrated safety and efficacy [28-29]. Similarly in osteoarthritis [30-31] and peripheral vascular disease [32-35] using bone marrow stem cells showed significant benefit security and to suppress pain and improve functional capacity.

In type 1 diabetes recently diagnosis reported significant increases in C-peptide after transplantation of allogeneic adult stem cells with immune suppression [36-38].

Our initial work using autologous bone marrow cells, without immune suppression, in chronic type 1 diabetes demonstrated the safety of the implantation technique through selective arterial catheterization and the effects on C-peptide increased to normal in 13 of 20 subjects at six months follow-up [39]. This report shows the three-year follow-up results of these 20 subjects.

\section{METHODS}

\subsection{Subject Recruitment}

With the authorization from the Ministry of Health of Argentina (INCUCAI) and the approval by the Institutional Ethical Committee of Hospital Santa Clara on the treatment protocol, informed consent (N168.05), a perspective non-randomized phase II clinical trial was designed. Eligible subjects were: age between 18 and 65 years, undetectable C-peptide level, and chronic type 1 diabetes mellitus for more than 5 years, with negative results of islet cell antibody (ICA) and glutamic acid decarboxylase (GAD) antibody. All enrolled subjects had antecedents of positive results of ICA and GAD antibody. Exclusion criteria: non-correctable artery diseases, bodymass index (the weight in kilograms divided by the square of the height in meters) $>28$, glycated hemoglobin $(\mathrm{HbA} 1 \mathrm{c})$ level $>10 \%$, inadequate renal reserve (serum creatinine $>1.5 \mathrm{mg} / \mathrm{dl}$, creatinine clearance $<80 \mathrm{ml}$ per minute per $1.73 \mathrm{~m}^{2}$ of body-surface area, or albumin level $>300 \mathrm{mg}$ per 24 hour period).

To confirm the eligibility, an endocrinologist independently assessed the subjects who received autologous bone marrow cell implantation. Optimized appropriate intensive glycemic monitoring and insulin therapy were failed in all subjects. We had interviewed 230 subjects with type 1 diabetes prospectively and enrolled 20 subjects who met the inclusion criteria for treatment from October 2005 to November 2006. Enrolled subjects and their families signed written informed consents. The other 210 subjects were rejected due to organic lesions seconddary to diabetes (100 p), less than 18 years old (36 p), no more than 5 years after diagnosis $(29$ p), not understand the procedure $(25 \mathrm{p})$, and $\mathrm{HbA} 1 \mathrm{c}>10 \%(20 \mathrm{p})$.

\subsection{Bone Marrow Cell Preparation and Transplantation}

Twenty enrolled subjects underwent bone marrow stimulation with $10 \mathrm{mg} / \mathrm{kg} /$ day of filgrastim (granulocyte colony stimulating factor, G-CSF) through subcutaneous injections for four consecutive days. On 5th day, bone marrow extraction was performed by trocar puncture on the posterior iliac crest of the hip with a local anesthesia application of $2 \%$ lidocaine. $100 \mathrm{ml}$ of bone marrow was aspirated and mixed with sodium heparin (1000 UI/40 $\mathrm{ml})$. No in vitro expansion procedure or cell culture was performed. 5 - $10 \mathrm{ml}$ of the sample was used for CD34 + cell counting with flow cytometry. The number and types of bone marrow cells injected through the catheter were also identified as $\mathrm{CMN}>1 \times 90$ and $\mathrm{CD} 34+>0.12 \times$ $106 / \mathrm{kg}$ ). A arterial sheath was placed into the right femoral artery after bone marrow puncture, and subsequently, a give french guide catheter (diameter on a $0.035-\mathrm{J}$ guide) was guided into the superior mesenteric artery or celiac trunk to identify pancreatic artery. $5000 \mathrm{IU}$ of sodium heparin was injected through the catheter. A micro catheter was selectively placed into the hepatic artery or dominant trunk with guide 0.014 and advanced distally into the pancreatic artery. The bone marrow cells were injected through the micro catheter with an injection speed of $2 \mathrm{ml}$ per minute to prevent back flow. Angiography was performed to confirm the selective catheterization into the pancreatic artery without vascular complications. No immunosuppression regimen was processed at preand post-treatment.

\subsection{Study Definitions and Measurements}

Major adverse events were considered as death, vascular complications at the injection site (embolism, thrombosis, dissection, vasospasm, and hematoma requiring surgery or blood transfusion), pulmonary embolism, acute pancreatitis, emergency abdominal surgery, absence of metabolic stability with major hypoglycaemia, post-transplantation lymphoproliferative disease, cancer, infections, and presence of abdominal tumours observed in echography. Increased measurement results of the ICA and GAD antibody were also considered as an adverse event.

The markedly effective treatment result was defined as the C-peptide level of at least $0.9 \mathrm{ng} / \mathrm{ml}$ with independ- 
ence of daily insulin application and adequate glycemic control at all evaluation points. The effective treatment result was the C-peptide level of at least $0.1 \mathrm{ng} / \mathrm{ml}$ with decreased daily insulin dose and inadequate glycemic control. The ineffective treatment result was defined as the C-peptide level $<0.05 \mathrm{ng} / \mathrm{ml}$. Insulin independence and adequate glycemic control were considered as $\mathrm{HbAlc}$ level $<6.5 \%$ and fasting glycemia $<100 \mathrm{mg} / \mathrm{dl}$ over three times per week, and 2-hour postprandial levels $<200$ $\mathrm{mg} / \mathrm{dl}$ over four times a week. The primary study endpoint was defined as normalization of C-peptide and $\mathrm{HbAlc}$ with insulin independence at 3 years post-treatment.

The C-peptide level in peripheral blood was measured with chemistry electroluminescence after 12-hour fasting. The plasmatic levels of $0.9-4.4 \mathrm{ng} / \mathrm{ml}$ were considered as the normal range with an analytical sensitivity of $0.005-0.040 \mathrm{ng} / \mathrm{ml}$. The HbA1c level was measured by the method of immuno-latex agglutination on particles with the standard values of $4.2 \%-6.2 \%$. The measurement of pancreatic ICA was performed using the ELISA technique. GAD antibodies were identified by radio immuno analysis with the normal value $<1 \mathrm{U} / \mathrm{ml}$ (negative).

\subsection{Follow-Up}

The subjects were phoned every 48 hours in the first three months after the cell implantation. Clinical evaluations were performed at baseline (pre-treatment) and month $6(6 \mathrm{~m}), 12(12 \mathrm{~m}), 24(24 \mathrm{~m})$ and $36(36 \mathrm{~m})$ posttreatment, including the measurements of $\mathrm{C}$-peptide, HbA1c, daily insulin dose, ICA, GAD antibody and abdominal echography.

\subsection{Statistical Analysis}

Testing was standardized for each sample or examination. Data were presented as means \pm standard deviations $( \pm \mathrm{s})$. Changes of $\mathrm{C}$-peptide and insulin doses between pre- and post-treatment were assessed using paired Wilcoxon signed ranks test and " $<0.05$ " was considered the minimum value of " 0.05 ". Variables between pre- and post-treatments of $\mathrm{HbAlc}$ were assessed using paired $\mathrm{T}$ test. All statistical analyses were performed using SPSS 12.0 statistical package. All statistical tests were twosided and a p-value $<0.05$ was considered statistically significant. The proportion was expected to reach the primary endpoint by $70 \%$ with a confidence interval (CI) of $95 \%$.

\section{RESULTS}

\subsection{Clinical Features}

Subject characteristics at pre-treatment: mean age 35.6 years (18 - 65 years), defined diagnosis of type 1 diabetes for 13.9 years on average ( 2 - 37 years), body mass index (median) of $28 \mathrm{~kg} / \mathrm{m}^{2}$, normal complete blood count, coagulation and renal function, no lesions in target organs, HbA1c level (median) of $8.23 \%(6.7 \%$ - 10.1\%), C-peptide level $<0.05 \mathrm{ng} / \mathrm{ml}$, negative results of ICA and GAD antibody, and the average proportion of CD34 + cells in peripheral blood before transplantation of $0.07 \%$ $(0.03 \%-0.22 \%)$.

\subsection{Adverse Events}

Nine subjects displayed bone pain immediately after the cell transplantation, which was secondary to bone marrow stimulation. Two subjects had nausea and five subjects showed bruising at the site of arterial puncture for catheterization. All these adverse effects were tolerable and relieved in a short time. There were no reports of death, post-transplantation lymphoproliferative diseases, tumors or infections. The examination results of abdominal echography were normal in all subjects and no subjects showed morphological changes during the follow-ups.

\subsection{C-Peptide}

All subjects' C-peptide values were less than $0.05 \mathrm{ng} /$ $\mathrm{ml}$ before cell implantation. At 6 months post-treatment, 13 subjects showed the significant elevation of C-peptide $(\mathrm{P}=0.001, \mathrm{CI}=95 \%)$. Six of these 13 subjects $(45 \%)$ reached normal values. 15 subjects showed the significant elevation of $\mathrm{C}$-peptide $(\mathrm{P}=0.001, \mathrm{CI}=95 \%)$ at 12 months post-treatment, in which 7 subjects $(45 \%)$ showed normal values. At 24 months post-treatment, 13 subjects showed the significant elevation $(\mathrm{P}=0.001, \mathrm{CI}=95 \%)$ and 6 of these 13 subjects $(45 \%)$ reached normal values. 10 subjects showed the significant elevation of C-peptide $(\mathrm{P}=0.005, \mathrm{CI}=95 \%)$ at 36 months post- treatment, in which 3 subjects (33\%) showed normal values (Table 1, Figure 1).

\subsection{Daily Insulin Dose}

The mean daily insulin dose utilized by all enrolled subjects was $48.55 \pm 23 \mathrm{U}$ before cell implantation. The subjects with elevated C-peptide levels presented a significant decrease in daily insulin dose and the subjects with normal C-peptide values stopped for daily insulin use after the treatment. At 6 months post-treatment, 13 subjects showed the significant decrease in daily insulin dose (means $20.15 \pm 17.4 \mathrm{U}, \mathrm{P}=0.0003, \mathrm{CI}=95 \%$ ) and 5 subjects stopped using insulin. 15 subjects showed the significant decrease (means $15.75 \pm 17.1 \mathrm{U}, \mathrm{P}=0.001$, $\mathrm{CI}=95 \%$ ) at 12 months post-treatment, in which 7 subjects stopped daily insulin use. At 24 months post-treatment, 13 subjects showed the significant decrease (means $20.15 \pm 19.4 \mathrm{U}, \mathrm{P}=0.0004, \mathrm{CI}=95 \%$ ) and 6 subjects stopped using insulin. At 36 months, 10 subjects showed 


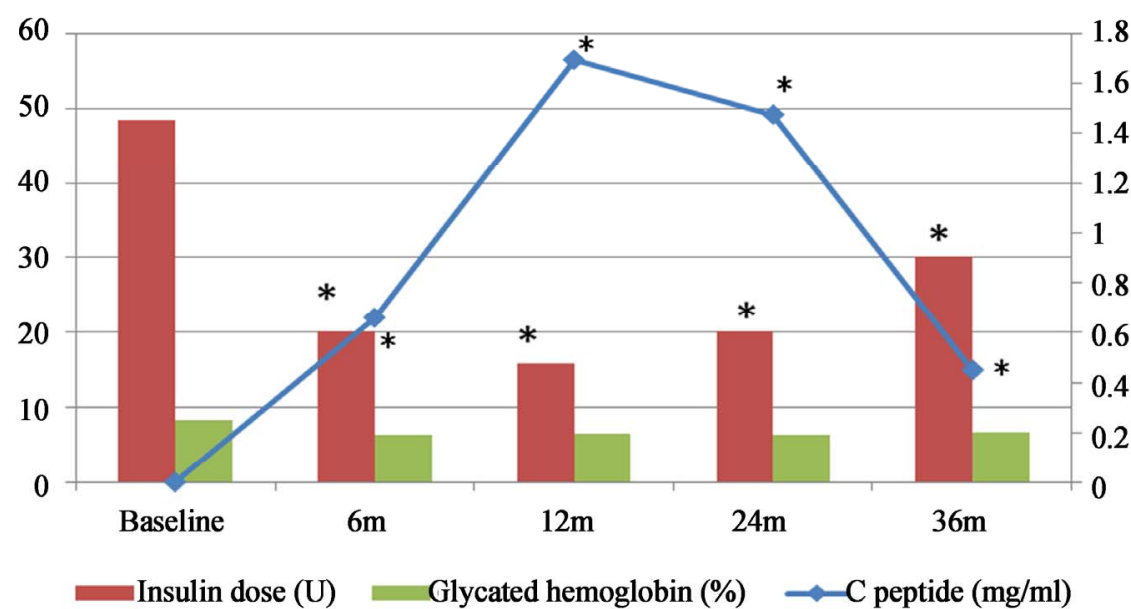

The C-peptide, daily insulin dose and glycated hemoglobin were measured in 20 subjects treated with bone marrow stem cell transplantation at baseline (pre-treatment) and 6, 12, 24 and 36 months post-treatment, respectively (displayed with mean values). " means that the values of $\mathrm{C}$-peptide and daily insulin dose at each follow-up point were significantly changed when compared to the baseline $(\mathrm{P} \leq 0.01)$.

Figure 1. Measurements of C-peptide, daily insulin dose and glycated hemoglobin.

Table 1. C-peptide values $(\mathrm{ng} / \mathrm{mL})$ at pre-treatment and follow-up points.

\begin{tabular}{|c|c|c|c|c|c|}
\hline Subject $(\mathrm{n}=20)$ & Baseline & $6 \mathrm{~m}$ & $12 \mathrm{~m}$ & $24 \mathrm{~m}$ & $36 \mathrm{~m}$ \\
\hline 1 & $<0.05$ & 1.4 & 2.54 & 2.54 & 2 \\
\hline 2 & $<0.05$ & 5 & 10 & 10 & $<0.05$ \\
\hline 3 & $<0.05$ & 1.22 & 0.9 & $<0.05$ & $<0.05$ \\
\hline 4 & $<0,05$ & 0.22 & 1.4 & 1.4 & $<0.05$ \\
\hline 5 & $<0,05$ & 0.9 & 0.8 & $<0.05$ & $<0.05$ \\
\hline 6 & $<0.05$ & 0.3 & 0.64 & 0.64 & 0.2 \\
\hline 7 & $<0.05$ & 0.36 & 0.3 & 0.3 & 0.3 \\
\hline 8 & $<0.05$ & $<0.05$ & $<0.05$ & $<0.05$ & $<0.05$ \\
\hline 9 & $<0.05$ & $<0.05$ & 0.9 & 1.1 & 0.3 \\
\hline 10 & $<0.05$ & 0.7 & 0.2 & $<0.05$ & $<0.05$ \\
\hline 11 & $<0.05$ & 0.2 & 0.44 & 0.44 & 0.44 \\
\hline 12 & $<0.05$ & 1.2 & 3.3 & 3 & 3 \\
\hline 13 & $<0.05$ & $<0.05$ & 0.57 & 0.57 & 0.57 \\
\hline 14 & $<0.05$ & $<0.05$ & $<0.05$ & $<0.05$ & $<0.05$ \\
\hline 15 & $<0.05$ & 0.77 & 0.65 & 0.6 & $<0.05$ \\
\hline 16 & $<0.05$ & 0.82 & $<0.05$ & $<0.05$ & $<0.05$ \\
\hline 17 & $<0.05$ & $<0.05$ & $<0.05$ & $<0.05$ & $<0.05$ \\
\hline 18 & $<0.05$ & 0.9 & 0.9 & 0.7 & 0.7 \\
\hline 19 & $<0.05$ & $<0.05$ & 0.4 & 1.2 & 1.2 \\
\hline 20 & $<0.05$ & $<0.05$ & $<0.05$ & 0.33 & 0.33 \\
\hline $\mathrm{P}$ & nc & 0.001 & 0.001 & 0.001 & 0.005 \\
\hline
\end{tabular}

the significant decrease in daily insulin dose (means $30.15 \pm 21.4 \mathrm{U}, \mathrm{P}=0.001, \mathrm{CI}=95 \%)$ at 36 months posttreatment, in which 3 subjects stopped daily insulin use (Table 2, Figure 1).

\subsection{Glycated Hemoglobin (HbA1c)}

The means of $\mathrm{HbAlc}$ was $8.23 \% \pm 0.9 \%$ before cell implantation. The subjects who had normal C-peptide values and stopped using insulin showed normal $\mathrm{HbAlc}$ levels. 5 subjects (means $6.2 \% \pm 0.4 \%, \mathrm{P}=0.229, \mathrm{CI}=$ $95 \%$ ), 7 subjects (means $6.5 \% \pm 0.6 \%, \mathrm{P}=0.221, \mathrm{CI}=$ $95 \%), 6$ subjects (means $6.2 \% \pm 0.5 \%, \mathrm{P}=0.055, \mathrm{CI}=$ $95 \%$ ) and 3 subjects (means $6.6 \% \pm 0.6 \%, \mathrm{P}=0.051, \mathrm{CI}$ $=95 \%$ ) showed normal HbAlc levels at 6, 12, 24 and 36 months post-treatment, respectively. However, there was no significant changes in $\mathrm{HbA} 1 \mathrm{c}$ levels at each follow-up points when compared to the baseline $(\mathrm{P}>0.05)$ (Table 3 , Figure 1).

\subsection{Sensitization}

All enrolled subjects had antecedents of positive results of ICA and GAD antibody when diagnosed and negative results when enrolled in this study. Negative results of ICA and GAD antibody were detected during the treatment and follow-ups.

\section{DISCUSSION}

The results demonstrated that the injection of bone marrow cells into the pancreatic microcirculation through catheterization is safe and easy to perform. No severe adverse events have been reported. Although side effects related to the bone marrow stimulation and catheteriza- 
Table 2. Daily insulin dose (U) at pre-treatment and follow-up points.

\begin{tabular}{|c|c|c|c|c|c|}
\hline $\begin{array}{l}\text { Subject } \\
(\mathrm{n}=20)\end{array}$ & Baseline & $6 \mathrm{~m}$ & $12 \mathrm{~m}$ & $24 \mathrm{~m}$ & $36 \mathrm{~m}$ \\
\hline 1 & 92 & 20 & 0 & 0 & 0 \\
\hline 2 & 94 & 0 & 0 & 0 & 80 \\
\hline 3 & 62 & 0 & 0 & 50 & 50 \\
\hline 4 & 88 & 20 & 0 & 0 & 30 \\
\hline 5 & 38 & 0 & 0 & 30 & 30 \\
\hline 6 & 50 & 10 & 10 & 10 & 40 \\
\hline 7 & 50 & 50 & 50 & 50 & 50 \\
\hline 8 & 66 & 50 & 55 & 55 & 55 \\
\hline 9 & 55 & 55 & 0 & 0 & 50 \\
\hline 10 & 50 & 10 & 12 & 48 & 48 \\
\hline 11 & 44 & 20 & 20 & 20 & 20 \\
\hline 12 & 40 & 0 & 0 & 0 & 0 \\
\hline 13 & 14 & 10 & 5 & 12 & 12 \\
\hline 14 & 30 & 26 & 30 & 30 & 30 \\
\hline 15 & 24 & 12 & 14 & 14 & 24 \\
\hline 16 & 26 & 20 & 26 & 26 & 26 \\
\hline 17 & 28 & 20 & 28 & 28 & 28 \\
\hline 18 & 30 & 0 & 0 & 10 & 10 \\
\hline 19 & 40 & 30 & 15 & 0 & 0 \\
\hline 20 & 50 & 50 & 50 & 20 & 20 \\
\hline $\bar{x} \pm \mathrm{s}$ & $48.55 \pm 23$ & $20.15 \pm 17.4$ & $5.75 \pm 17$. & $20.15 \pm 19.4$ & $30.15 \pm 21.4$ \\
\hline$P$ & $\mathrm{nc}$ & 0.0003 & 0.001 & 0.0004 & 0.001 \\
\hline
\end{tabular}

tion were observed, these were easily managed.

The endocrine function of pancreas was reactivated after bone marrow cell transplantation as shown by the increased level of C-peptide, demonstrating that the secretion of pancreatic insulin was reassumed. The decreased daily insulin dose and $\mathrm{HbA} 1 \mathrm{c}$ level indicated that metabolic control was reestablished. During follow-ups, 15 subjects achieved functional implants, in which 8 subjects showed partial functional implants and 7 subjects reached the primary endpoint. The increased Cpeptide level and decreased daily insulin dose showed statistical significance after bone marrow cell transplantation. This improvement in metabolic control could be secondary to the improvement in pancreatic function. This clinical improvement was evident with episodes of hypoglycemia but was never severe.

Those results evidenced a beneficial effect of the bone marrow cell implantation on subjects with chronic type 1
Table 3. Glycated hemoglobin (\%) values at pre-treatment and follow-up points.

\begin{tabular}{|c|c|c|c|c|c|}
\hline $\begin{array}{l}\text { Subject } \\
(\mathrm{n}=20)\end{array}$ & Baseline & $6 \mathrm{~m}$ & $12 \mathrm{~m}$ & $24 \mathrm{~m}$ & $36 \mathrm{~m}$ \\
\hline 1 & 8.2 & 7 & 5.9 & 5.9 & 6 \\
\hline 2 & 8.5 & 6 & 6 & 6 & 8 \\
\hline 3 & 9.5 & 8.7 & 6 & 6 & 6.5 \\
\hline 4 & 7 & 9.2 & 6 & 6 & 7 \\
\hline 5 & 6.9 & 6 & 8.1 & 8.1 & 7.5 \\
\hline 6 & 8.5 & 7 & 10 & 10 & 8 \\
\hline 7 & 8.1 & 8.4 & 8 & 8.3 & 8 \\
\hline 8 & 7.5 & 7.6 & 6.5 & 6.5 & 6.7 \\
\hline 9 & 7.8 & 7.5 & 7 & 7 & 7 \\
\hline 10 & 7.5 & 8 & 8.7 & 8.7 & 8.7 \\
\hline 11 & 9.4 & 6 & 7.2 & 8 & 7.8 \\
\hline 12 & 9.9 & 8 & 5.9 & 6 & 6 \\
\hline 13 & 6.7 & 7.9 & 11 & 7.4 & 8 \\
\hline 14 & 8 & 7 & 9 & 7.6 & 7.6 \\
\hline 15 & 8.09 & 9.8 & 8.06 & 9 & 9 \\
\hline 16 & 8.91 & 6.9 & 7 & 9 & 9 \\
\hline 17 & 7.16 & 8.2 & 9 & 8.5 & 8.5 \\
\hline 18 & 8.3 & 8.8 & 6.5 & 7 & 7 \\
\hline 19 & 9.1 & 8.1 & 8 & 6 & 6 \\
\hline 20 & 9.2 & 10 & 9 & 8 & 8 \\
\hline $\bar{x} \pm \mathrm{s}$ & $8.23 \pm 0.9$ & $6.2 \pm 0.4$ & $6.5 \pm 0.6$ & $6.2 \pm 0.5$ & $6.6 \pm 0.6$ \\
\hline $\mathrm{P}$ & $\mathrm{nc}$ & 0.229 & 0.221 & 0.055 & 0.051 \\
\hline
\end{tabular}

diabetes, though we cannot describe the exact mechanisms involved in this study. It has been suggested that the bone marrow cell transplantation can reactivate the pancreatic function. The biological mechanism may be the activation of pancreatic stem cells, which might be passivated inside the pancreas, by transplanted stem cells and growth factors or cytokines produced by these cells. The pancreatic stem cells and transplanted bone marrow stem cells might be recruited through the mediation of the pancreatic cytokines and ultimately initiated cell regeneration by differentiation. Lanus et al. [21] obtained stem cells from male mice expressing the CRE-LoxO system with green fluorescent protein and were injected into the female mice, which were lethally irradiated to stop secreting insulin. After 4 to 6 weeks, islets of Langerhans with $\mathrm{Y}$ chromosome marked with fluorescein were observed in the pancreas of the female mice. This experiment was the first one to describe the cellular migration and its dif- 
ferentiation without evidence of cellular fusion. Sordi et al. [22] demonstrated that the cytokines involved in the migration of bone marrow stem cells and stimulation of cell differentiation towards $\beta$ cells with secretion of insulin are CX3CL12 and CX3CL1. Various research teams corroborated the mechanisms.

In addition, it has been demonstrated that pancreatic chemokines could promote the aggregation of bone marrow mononuclear and progenitor cells transplanted into the pancreatic circulation and these cells and their secreted growth factors provoked the activation of quiescent stem cells that differentiated into insulin-secreting pancreatic cells. Our results in this study are consistent with this observations carried out in vitro and in animals. We observed an increase of the C-peptide at four months after cell transplantation [39], which maintained the significant level up to three years after treatment. Partial functional implants were observed in $33 \%$ of subjects and total functional implants in another $33 \%$ of subjects. The subjects with normal levels of C-peptide did not require daily exogenous insulin to control the glycemia and this effect was translated in normalization of HbA1c levels. Voltareli et al [36] and Weiqiong [37] have achieved the similar results after transplanted bone marrow cells into subjects who recently diagnosed with type 1 diabetes from autoimmune attack.

Our work is the first clinical experience without immunosuppression during the bone marrow cell transplanttation. The results are clinically significant and persistent for three years. A recent clinical trial has concluded that bone marrow stem cells transplantation with immunosuppression showed safety, tolerability and effectiveness in most of 200 subjects recently diagnosed with type 1 diabetes, but immunosuppression caused major complications [38]. Comparing this study with our experience, no significant differences have been observed in the rates of disease progression, as measured by the stimulated Cpeptide levels at one year follow-up point.

In addition, the implantation technique in this study might generate a high number of bone marrow stem cells arrived to the affected area, which could justify the use of local implants. It may be considerable that cell transplantation through systemic intravenous injection could not achieve a high and effective cell numbers at the affected tissues, due to circulatory dispersion, and consequently showed no evident clinical results. One study demonstrated that $70 \%$ of stem cells released into the venous circulation stopped in the lung and only a small amount of cells arrived to the heart, kidneys and liver [40].

A few subjects showed metabolic degradation with the deteriorated levels of C-peptide and required daily use of exogenous insulin after three years post-treatment. This indicated the destruction of new pancreatic $\beta$ cells but the mechanism of cellular damage has not been clarified. However, it is difficult to establish a clear-cut relationship with a new attack of autoimmune antibodies as the negative results of ICA and GAD antibody were still observed during the follow-ups.

\section{CONCLUSION}

No doubt, the progressively decreased level of C-peptide in subjects with chronic type 1 diabetes is well known and the spontaneous remission has never been observed after current standard medical treatments. This study suggested that autologous bone marrow cell transplantation through pancreatic artery catheterization may be a safe and effective therapeutic strategy for patients with chronic type 1 diabetes. The three-year follow-up results showed the restoration of pancreatic function with a significant increase of C-peptide and consequently decreased daily dose of exogenous insulin. Although this effect partially disappears by the three year follow-up without an increase of ICA and GAD antibody, this treatment might be an alternative to insulin treatment and an option to improve the life quality of patients with type 1 diabetes and delay the onset of complications. Based on the current data, further double-blind placebo controlled studies are warranted to further validate the long-term safety and efficacy.

\section{REFERENCES}

[1] Gianani, R., Campbell-Thompson, M., Sarkar, S.A., et al. (2010) Dimorphic histopathology of long-standing childhood-onset diabetes. Diabetologia, 53, 690-698. doi:10.1007/s00125-009-1642-y

[2] Madsbad, S., Krarup, T., Regeur, L., Faber, O.K. and Binder, C. (1980) Insulin secretory reserve in insulin dependent patients at time of diagnosis and the first 180 days of insulin treatment. Acta Endocrinologica, 95, 359-363.

[3] Steele, C., Hagopian, W.A., Gitelman, S., et al. (2004) Insulin secretion in type 1 diabetes. Diabetes, 53, 426-433. doi: $10.2337 /$ diabetes.53.2.426

[4] Eff, Ch., Faber, O. and Deckert, T. (1978) Persistent insulin secretion, assessed by plasma C-peptide estimation in long-term juvenile diabetics with a low insulin requirement. Diabetologia, 15, 169-172. doi:10.1007/BF00421234

[5] Nakanishi, K. and Watanabe, C. (2008) Rate of b-cell destruction in type 1 diabetes influences the development of diabetic retinopathy: Protective effect of residual b-cell function for more than 10 years. The Journal of Clinical Endocrinology \& Metabolism, 93, 4759-4766. doi:10.1210/jc.2008-1209

[6] Liu, E.H., Digon, B.J., Hirshberg, B., et al. (2009) Pancreatic beta cell function persists in many patients with chronic type 1 diabetes, but is not dramatically improved by prolonged immunosuppression and euglycaemia from 
a beta cell allograft. Diabetologia, 52, 1369-1380. doi:10.1007/s00125-009-1342-7

[7] Madsbad, S., Faber, O.K., Binder, C., McNair, P., Christiansen, C. and Transbøl, I. (1978) Prevalence of residual beta-cell function in insulin dependent diabetics in relation to age at onset and duration of diabetes. Diabetes, 27, 262-264.

[8] Ramiya, V.K., Maraist, M., Arfors, K.E., Schatz, D.A., Peck, A.B. and Cornelius, J.G. (2000) Reversal of insulin-dependent diabetes using islets generated in vitro from pancreatic stem cells. Nature Medicine, 6, 278-282. doi: $10.1038 / 73128$

[9] Dor, Y., Brown, J., Martinez, O.I. and Melton, D.A. (2004) Adult pancreatic-cells are formed by self-duplication rather than stem-cell differentiation. Nature, 429, 41-46. doi:10.1038/nature 02520

[10] de la Tour, D., Halvorsen, T., Demeterco, C., Tyrberg, B., Itkin-Ansari, P., Loy, M., Loo, S.J., Hao, E., Bossie, S. and Levine, F. (2001) Beta-cell differentiation from a human pancreatic cell line in vitro and in vivo. Molecular Endocrinology, 15, 476-483. doi:10.1210/me.15.3.476

[11] Chen, L.B., Jiang, X.B. and Yang, L. (2004) Differentiation of rat marrow mesenchymal stem cells into pancreatic islet beta-cells. World Journal of Gastroenterology, 10, 3016-3020.

[12] Venstrom, J.M., McBride, M.A., Rother, K.I., Hirshberg, B., Orchard, T.J. and Harlan, D.M. (2003) Survival after pancreas transplantation in subjects with diabetes and preserved kidney function. JAMA, 290, 2817-2823. doi:10.1001/jama.290.21.2817

[13] Shapiro, A.M.J., Ricordi, C., Hering, B.J., Auchincloss, H., Lindblad, R., Robertson, R.P., Secchi, A., Brendel, M.D., Berney, T., Brennan, D.C., Cagliero, E., Alejandro, R., Ryan, E.A., DiMercurio, B., Morel, P., Polonsky, K.S., Reems, J.-A., Bretzel, R.G., Bertuzzi, F., Froud, T., Kandaswamy, R., Sutherland, D.E.R., Eisenbarth, G., Segal, M., Preiksaitis, J., Korbutt, G.S., Barton, F.B., Viviano, L., Seyfert-Margolis, V., Bluestone, J. and Lakey, J.R.T. (2006) International trial of the edmonton protocol for islet transplantation. The New England Journal of Medicine, 355, 1318-1330.

[14] Ferrari, G., Cusella-De, A.G., Coletta, M., et al. (1998) Muscle regeneration by bone marrow-derived myogenic progenitors. Science, 279, 1528-1530. doi:10.1126/science.279.5356.1528

[15] Hakuno, D., Fukuda, K., Makino, S., et al. (2002) Bone marrow-derived regenerated cardiomyocytes (CMG Cells) express functional adrenergic and muscarinic receptors. Circulation, 105, 380-386. doi:10.1161/hc0302.102593

[16] Laflamme, M.A., Myerson, D., Saffitz, J.E. and Murry, C.E. (2000) Evidence for cardiomyocyte repopulation by extracardiac progenitors in transplanted human hearts. Circulation Research, 90, 634-640. doi:10.1038/35018642

[17] Alison, M.R., Poulsom, R., Jeffery, R., Dhillon, A.P., Quaglia, A., Jacob, J., Novelli, M., Prentice, G., Williamson, J. and Wright, N.A. (2000) Hepatocytes from nonhepatic adult stem cells. Nature, 406, 257. $\underline{\text { doi: } 10.1038 / 35018642}$
[18] Poulsom, R., Forbes, S.J., Hodivala-Dilke, K., Ryan, E., Wyles, S., Navaratnarasah, S., Jeffery, R., Hunt, T., Alison, M., Cook, T., Pusey, C. and Wright, N.A. (2001) Bone marrow contributes to renal parenchymal turnover and regeneration. The Journal of Pathology, 195, 229-235. doi:10.1002/path.976

[19] Kopen, G.C., Prockop, D.J. and Phinney, D.G. (1999) Marrow stromal cells migrate throughout forebrain and cerebellum, and they differentiate into astrocytes after injection into neonatal mouse brains. Proceedings of the National Academy of Sciences, 96, 10711-10716. doi:10.1073/pnas.96.19.10711

[20] Bonner-Weir, S., Taneja, M., Weir, G.C., Tatarkiewicz, K., Song, K.H., Sharma, A. and O'Neil, J.J. (2000) In vitro cultivation of human islets from expanded ductal tissue. Proceedings of the National Academy of Sciences, 97, 7999-8004. doi:10.1073/pnas.97.14.7999

[21] Ianus, A., Holz, G., Theise, N.D. and Hussain, M. (2003) In vivo derivation of glucose-competent pancreatic endocrine cells from bone marrow without evidence of cell fusion. Journal of Clinical Investigation, 111, 843-850.

[22] Sordi, V., Malosio, M.L., Marchesi, F., Mercalli, A., Melzi, R., Giordano, T., Belmonte, N., Ferrari, G., Leone, B., Bertuzzi, F., Zerbini, G., Allavena, P., Bonifacio, E. and Piemonti, L. (2005) Bone marrow mesenchymal stem cells express a restricted set of functionally active chemokine receptors capable of promoting migration to pancreatic islets. Telethon-Juvenile Diabetes Research Foundation Center for Cell Replacement, University of Milano-Bicocca, Milan.

[23] Assmus, B., Schächinger, V. and Teupe, C. (2002) Transplantation of progenitor cells and regeneration enhancement in acute myocardial infarction (TOPCARE-AMI). Circulation, 106, 3009-3017. doi:10.1161/01.CIR.0000043246.74879.CD

[24] Strauer, B.E., Brehm, M., Zeus, T., Kostering, M., Hernández, A., Sorg, R.V., et al. (2002) Repair of infarcted myocardium by autologous intracoronary mononuclear bone marrow cell transplantation in humans. Circulation, 106, 1913-1918. doi:10.1161/01.CIR.0000034046.87607.1C

[25] Fernández-Avilés, F., San Román, J.A., García-Frade, J., Fernández, M.E., Penarrubia, M.J., De la Fuente, L., et al. (2004) Experimental and clinical regenerative capability of human bone marrow cells after myocardial infarction. Circulation Research, 95, 742-748. doi:10.1161/01.RES.0000144798.54040.ed

[26] Wollert, K.C., Meyer, G.P., Lotz, J., Ringes-Lichtenberg, S., Lippolt, P., Breidenbach, C., et al. (2004) Intracoronary autologous bone-marrow cell transfer after myocardial infarction: The BOOST randomised controlled clinical trial. Lancet, 364, 141-148. doi:10.1016/S0140-6736(04)16626-9

[27] Schachinger, V., Erbs, S., Elsasser, A., Haberbosch, W., Hambrecht, R., Holschermann, H., et al. (2006) Intracoronary bone marrow-derived progenitor cells in acute myocardial infarction. The New England Journal of Medicine, 355, 1210-1221. doi:10.1056/NEJMoa060186

[28] Hahn, T., Wall, D., Camitta, B., et al. (2005) The role of 
cytotoxic therapy with hematopoietic stem cell transplanttation in the therapy of acute lymphoblastic leukemia in children: An evidence-based review. Biology of Blood and Marrow Transplantation, 11, 823-861. doi:10.1016/j.bbmt.2005.08.035

[29] Sanders, J.E., Im, H.J., Hoffmeister, P.A., et al. (2005) Allogeneic hematopoietic stem cell transplantation for infants with acute lymphoblastic leukemia. Blood, 105, 3749-3756. doi:10.1182/blood-2004-08-3312

[30] Centeno, C.J., Schultz, J.R., Cheever, M., Robinson, B., Freeman, M. and Marasco, W. (2010) Safety and complications reporting on the re-implantation of culture-expanded mesenchymal stem cells using autologous platelet lysate technique. Current Stem Cell Research \& Therapy, 5, 81-93.

[31] Ripoll, P.L., De Prado, M. and Yelo, J. (2009) Osteonecrosis of the knee. Perfusion of iliac crest mesenchymal cells. Trauma, 20, 211-220.

[32] Pesce, M., Orlandi, A., Iachininoto, M.G., Straino, S., Torella, A.R., Rizzut, V., et al. (2003) Myoendothelial differentiation of human umbilical cord blood derived stem cells in ischemic limb tissues. Circulation Research, 93, e51-e62. doi:10.1161/01.RES.0000090624.04507.45

[33] Vicario, J.H., Campo, C.D., Gerardo, L.E., Pfeffer, H., Ortega, H.H., Agustín Yosviak, A., et al. (2008) Angiogenesis in severe peripheral arterial disease with intraarterial administration of unfractionated autologous bone marrow. Phase I. Revista de la Federacion Argentina de Cardiologia, 37, 301-309.

[34] Huang, P.P., Li, S.Z., Han, M.Z., Xiao, Z.J., Yang, R.C., Qiu, et al. (2004) Autologous transplantation of peripherals blood stem cells as an effective therapeutic approach for severe arteriosclerosis obliterans of lower extremities. Journal of Thrombosis and Haemostasis, 91, 606-609.
[35] Huang, P., Li, S., Han, M., Xiao, Z., Yang, R. and Han, Z.C. (2005) Autologous transplantation of granulocyte colony-stimulating factor-mobilized peripheral blob mononuclear cell improves critical limb ischemia in diabetes. Diabetes Care, 28, 2155-2160. doi:10.2337/diacare.28.9.2155

[36] Couri, C., Oliveira, M., Stracieri, A., Moraes, D., Pieroni, F., Barros, G., Madeira, M.I., Malmegrim, K., FossFreitas, M., Simões, B., Martinez, E., Foss, M., Burt, R.K. and Voltarelli, J.C. (2009) C-peptide levels and insulin independence following autologous nonmyeloablative hematopoietic stem cell transplantation in newly diagnosed type 1 diabetes mellitus. JAMA, 301, 1573-1579. doi:10.1001/jama.2009.470

[37] Gu, W.Q., Hu, J., Wang, W.Q., Li, L.R., Tang, W., Sun, S.Y., Cui, W.J., et al. (2012) Diabetic ketoacidosis at diagnosis influences complete remission after treatment with hematopoietic stem cell transplantation in adolescents with type 1 diabetes. Diabetes Care, 35, 1413-1419. doi:10.2337/dc11-2161

[38] Fotino, C., Ricordi, C., Lauriola, V., Alejandro R. and Pileggi, A. (2012) Bone marrow-derived stem cell transplantation for the treatment of insulin-dependent diabetes. The Review of Diabetic Studies, 7, 144-157. doi:10.1900/RDS.2010.7.144

[39] Mesples, A.D., Pretiñe, B. and Bellomo, R. (2007) Treatment of type 1 diabetes mellitus with pancreatic implant of au- tologous adult stem cell. Endocrinología y $\mathrm{Nu}$ trición, 54, 512-518. doi:10.1016/S1575-0922(07)71497-3

[40] Herreros, J., Chaques, J., Trainini, J., Ponton, A., Sarralde, A. and Genovese, J. (2011) Cardiac cell regeneration. Circle Cardiovascular, 18, 207-215. 